\title{
PERBANDINGAN PENDAPATAN USAHATANI CAMPURAN BERDASARKAN PENGELOMPOKAN JENIS TANAMAN
}

\author{
Jefier Andrew Kuheba \\ Joachim N.K Dumais \\ Paulus A. Pangemanan
}

\begin{abstract}
The objective of research is to compare how much the average income per hectare of farms mixture by grouping types of plants in the Airmadidi Bawah Village. This research was conducted in the Airmadidi Bawah urban village for 3 months, from September to November 2015 with the method of data collection by using primary data. Samples taken were 15 for each farming mix using cluster random sampling technique. To determine the ratio mix used farm income analysis tool SPSS by using t-test. The results showed that there were significant differences between $1^{\text {st }}$ mixed farming with $2^{\text {nd }}$ mixed farming; the average income per hectare of $1^{\text {st }}$ mixed farming Rp. 35.921.389,- was higher than the average income per hectare of $2^{\text {nd }}$ mixed farming Rp. 30.430.699,Results of testing the hypothesis $1^{\text {st }}$ mixed farming and $2^{\text {nd }}$ mixed farming shows the $t$-test $(4.910)>t$ table (1,761). From the test results, Ho is rejected and $H 1$ is accepted, it means that there are differences in the average income per hectare of the $1^{\text {st }}$ mixed farming and $2^{\text {nd }}$ mixed farming.jnkd
\end{abstract}

Keyword : farms mixture, grouping types of plants, Airmadidi Bawah, North Minahasa

\begin{abstract}
ABSTRAK
Penelitian ini bertujuan membandingkan berapa besar pendapatan rata-rata per hektar usahatani campuran berdasarkan pengelompokan jenis tanaman di Kelurahan Airmadidi Bawah. Penelitian ini dilaksanakan di Lingkungan VII Kelurahan Airmadidi Bawah selama 3 bulan, sejak bulan September sampai November 2015 dengan metode pengambilan data menggunakan data primer. Sampel diambil sebanyak 15 untuk masing usahatani campuran dengan menggunakan teknik cluster random sampling. Untuk mengetahui perbandingan pendapatan usahatani campuran digunakan alat analisis SPSS dengan uji-t. Hasil penelitian menunjukan bahwa terdapat perbedaan pendapatan yang nyata antara usahatani campuran 1 dengan usahatani campuran 2, pendapatan ratarata per hektar usahatani campuran 1 sebesar Rp 35.921.389 lebih tinggi dari pendapatan rata-rata per hektar usahatani campuran 2 yaitu sebesar Rp 30.430.699. Hasil pengujian hipotesis usahatani campuran 1 dan usahatani campuran 2 menunjukan t-hitung $(4,910)>$ t-tabel $(1,761)$. Dari hasil pengujian maka, Ho di tolak dan $\mathrm{H} 1$ di terima, itu berarti bahwa terdapat perbedaan rata-rata pendapatan per hektar antara usahatani campuran 1 dengan usahatani campuran 2 .
\end{abstract}

Kata Kunci: usahatani campuran, pengelompokan jenis tanaman, Kelurahan Airmadidi Bawah, Kabupaten Minahasa Utara

\section{PENDAHULUAN}

\section{Latar Belakang}

Pertanian, yaitu kegiatan manusia untuk mengembangbiakkan tumbuhan dan hewan dengan maksud agar lebih baik dalam arti kuantitas, kualitas dan ekonomis. Artinya dengan biaya produksi yang rendah menghasilkan produksi yang tinggi dengan kualitas yang lebih baik seperti tahan hama atau penyakit. Pada taraf ini manusia telah mulai berusaha dengan tujuan tertentu.

Menurut Rochaeni (2014) Pertanian merupakan penunjang dalam kesejahteraan masyarakat untuk pemenuhan kebutuhan pangan. Saat ini produksi pangan menjadi permasalahan karena tidak seimbang dengan kebutuhan masyarakat, sehingga dibutuhkan usaha untuk meningkatkan produksi pertanian dalam menjawab permasalahan krisis pangan. 
Pertanian sebagai penghasil pangan, sandang dan papan yang terlihat nyata, petani juga memberikan multifungsi bagi masyarakat umum, selain memberi barang, petani juga memberikan jasa linkungan, selain itu pertanian juga menjaga ketahanan pangan, penyangga ekonomi dalam keadaan krisis, penyedia lapangan kerja.

Pembangunan pertanian pada hakekatnya lebih ditekankan pada peningkatan kesejahteraan petani pada umumnya, masyarakat pedesaan khususnya yang dapat dicapai melalui peningkatan nilai tambah, penganekaragaman hasil pertanian guna memenuhi kebutuhan pangan, bahan baku industri, mendorong perluasan dan pemerataan kesempatan berusaha dan lapangan kerja serta mendukung kegiatan pembangunan wilayah. Bagi produk pertanian hal tersebut meliputi seluruh sistem agribisnis, mulai dari hulu antara lain : pengadaan bibit, sarana produksi, pola tanam, proses budidaya hingga hilir yaitu penanganan pasca panen, industri pengolahan kegiatan perdagangan, institusi pasar, jasa penunjang atau kelembagaan termasuk kemampuan petani produsen.

Usahatani sendiri pada dasarnya merupakan bentuk interaksi antara manusia dan alam dimana terjadi saling mempengaruhi antara manusia dan alam sekitarnya. Akses petani sangat kecil terlebih dengan arus deras alih fungsi lahan, yang makin memperkecil akses dan mempersempit wilayah produksi pertanian. Usahatani yang ada kebanyakan hanya berskala kecil yang hanya mampu menghidupi kehidupan sehari-hari, usaha tani umumnya sangat kecil dalam berbagai bidang karena keterbatasan asset produktif, modal kerja, daya tawar menawar transaksi dan kekuatan politik ekonomi sehingga usaha tani tidak dapat berkembang secara dinamis. Usahatani campuran merupakan metode yang digunakan petani dalam meningkatkan produksi hasil pertanian dimana dalam satu musim tanam petani menanam lebih dari satu jenis tanaman dengan tujuan untuk menambah nilai ekonomi pada lahan usahatani tersebut.

Di kutip dari skripsi Tigauw (1998) didalam usahatani pendapatan mengandung dua pengertian, yaitu: pengertian praktis dan pengertian teknis. Pendapatan dalam pengertian praktis adalah balas jasa dari unsur-unsur produksi yang diterima oleh petani atau manajer atau pemilik unsur produksi tertentu. Dalam pengertian teknis pendapatan adalah selisih antara penerimaan dengan pengeluaran dalam produksi usahatani yang dihitung dalam suatu jangka waktu tertentu.

Warga Buton berasal dari daerah Sulawesi Tenggara dengan penghasil aspal yang kemudian bermigrasi ke daerah Bitung, pada tahun 1978 warga Buton ke daerah Airmadidi dengan jumlah $7 \mathrm{kk}$, pada tahun 2008 Airmadidi melakukan pemekaran dan warga Buton masuk Lingkungan VII Kelurahan Airmadidi Bawah sampai sekarang dengan jumlah kk 157 dan jumlah jiwa 664. Sebelum masuk ke daerah Airmadidi warga Buton sebelumnya berada di daerah Bitung yang sebagian besar bermata pencarian sebagai nelayan. Sebagian besar masyarakat Buto yang tinggal di daerah Airmadidi bermata pencarian petani dengan menanam berbagai macam rempah-rempah seperti jahe, sereh, cabe, kunyit serta tanaman lain seperti jagung, sayur, kacang tanah dan terong. Dalam meningkatkan pendapatan, petani yang ada memanfaatkan lahan yang ada dengan sebaik-baiknya untuk memproduksi komoditi pertanian baik untuk dipasarkan maupun di konsumsi untuk kehidupan sehari-hari. Dari latar belakang diatas peneliti mengadakan penelitian dengan judul "Perbandingan Pendapatan Usahatani Campuran Berdasarkan Pengelompokan Jenis Tanaman (Studi Kasus Kelurahan Airmadidi Bawah)".

\section{Usahatani}

Usahatani sebagai organisasi dari alam, kerja dan modal yang ditujukan kepada produksi dilapangan pertanian. Organisasi ini ketatalaksanaannya berdiri sendiri dan sengaja diusahakan oleh seorang atau sekumpulan, segolongan sosial, baik yang terikat genologis, politis maupun territorial sebagai pengelolanya. Dalam Suratiyah (2015) Berdasarkan tujuan dan prinsip sosial ekonomi, perkembangan usahatani digolongkan dalam 3 golongan sebagai berikut.

a. Usahatani yang memiliki ciri-ciri ekonomis capitalis misalnya perusahaan pertanian/perkebunan di Indonesia yang berbadan hukum. Dalam hal ini pengelolaan perusahaan terpisah dengan pengelolaan rumah tangga. Orientasi usaha pada komoditas yang dipasarkan 
untuk memperoleh keuntungan yang sebesar-besarnya.

b. Usahatani yang memiliki dasar ekonomissosialistis-komunitas. Misalnya sovchos dan kolchos yang ada di Rusia. Usahatani golongan ini menganggap tenaga kerja manusia sebagai faktor yang terpenting, mampu meberikan nilai lebih sehingga tenaga kerja yang dihargai dengan sangat istimewa. Tujuan utamanya adalah memproduksi hasil bumi untuk keperluan masyarakat banyak dan diatur secara sentral menurut rencana pemerintah.

c. Usahatani yang memiliki ciri-ciri ekonomis seperti yang diuraikan oleh A. Tshajanov yaitu family farming yang berkembang dari subsistence farming ke commercial farming.

Pada dasarnya perkembangan usahatani hanya bertujuan menghasilkan bahan pangan untuk kebutuhan keluarga sehingga hanya merupakan usahatani swasembada atau subsistence. Oleh karena sistem pengelolaan yang lebih baik maka dihasilkan produk berlebih dan dapat dipasarkan sehingga bercorak usahatani swasembada keuangan. Pada akhirnya karena berorientasi pada pasar maka menjadi usahatani niaga. Usahatani pada mulanya hanya mengelola tanaman pangan kemudian berkembang meliputi berbagai komoditi sehingga bukan usahatani murni tetapi menjadi usahatani campuran (mixed farming). Menurut Suratiyah (2015) usahatani campuran meliputi berbagai macam komoditas, antara lain tanaman pangan, hortikultura (sayur, buah-buahan, tanaman hias) dan tanaman perkebunan.

Secara garis besar, menurut Suratiyah (2015) ada dua bentuk usahatani yang telah dikenal yaitu usahatani keluarga (family farming) dan perusahaaan pertanian (plantation, estate, enterprise), umumnya yang dimaksud dengan usahatani adalah usaha keluarga sedangkan yang lain adalah perusahaan pertanian. Perbedaan pokok antara usahatani keluarga dan perusahaan pertanian terletak pada 8 hal, yakni sebagai berikut:

1. Tujuan Akhir.

Tujuan akhir usahatani keluarga adalah pendapatan keluarga petani (family farm income) yang terdiri atas laba, upah tenaga keluarga dan bunga modal sendiri. Pendapatan yang dimaksud adalah selisih antara nilai produksi dikurangi dengan biaya yang betul-betul dikeluarkann oleh petani. Laba, upah tenaga keluarga dan bunga modal sendiri dianggap suatu kesatuan yang tidak dapat dipisahkan lagi. Sementara perusahaan pertanian tujuan akhirnya adalah keuntungan atau laba yang sebesar-besarnya, yaitu selisih antara nilai hasil produksi dikurangi dengan biaya.

2. Bentuk Hukum.

Usahatani keluarga tidak berbadan hukum, sedangkan perusahaan pertanian pada umumnya memiliki badan hukum, misalnya PT. firma dan CV.

3. Luas Usaha.

Usahatani keluarga umumnya berlahan sempit yang biasanya disebut petani gurem karena penggunaan lahan kurang dari 0,5 ha. Sedangkan perusahaan pertanian pada umumnya berlahan luas karena orientasinya pada efisiensi dan keuntungan.

4. Jumlah Modal.

Usahatani keluarga mempunyai modal per satuan luas lebih kecil dibandingkan dengan perusahaan pertanian.

5. Jumlah Tenaga Yang Dicurahkan.

Jumlah tenaga yang dicurahkan per satuan luas usahatani keluarga lebih besar daripada perusahaan pertanian.

6. Unsur Usahatani.

Unsur usahatani keluarga dengan perusahaan pertanian dibedakan pada tenaga luar yang dibayar. Pada usahatani keluarga melibatkan petani keluarga serta tenaga luar, sedangkan perusahaan pertanian hanya tenaga luar yang dibayar. Unsur lainnya berupa tanah dan alam sekitarnya serta modal merupakan unsur yang dimiliki baik usahatani keluarga maupun perusahaan pertanian.

7. Sifat Usahatani.

Sifat usahatani keluarga pada umumnya bersifat subsistence, komersial, maupun semi komersial (transisi dari subsistence ke komersial). Sementara perusahaan pertanian selalu bersifat komersial, artinya selalu mengejar keuntungan dengan memperhatikan kualitas maupun kuantitas produksinya.

8. Pemanfaatan Terhadap Hasil-Hasil Pertanian.

Perusahaan pertanian selalu berusaha untuk memanfaatkan hasil-hasil pertanian yang mutakhir, bahkan tidak segan membiayai penelitian demi kemajuan usahanya. Perusahaan pertanian biasanya mempunyai bagian penelitian dan pengembangan yang 
berfungsi untuk mencari dan menemukan terobosan baru baik dari segi teknik bercocok tanam, pengolahan hasil maupun pemasarannya. Sementara usahatani keluarga karena keterbatasan modal, peralatan dan human capital maka terobosan-terobosan baru tergantung pada hasil penelitian dan pengembangan pemerintah melalui departemen pertanian dengan balai penelitian dan pengembangan teknologi serta tenaga-tenaga penyuluh. Petani menerapkan hasil-hasil penelitian tersebut setelah mengamati dan mengikuti demonstrasi plot serta upaya-upaya sosialisasi yang dilakukan pemerintah lainnya.

\section{Klasifikasi Biaya Dalam Usahatani}

Biaya usahatani dapat dikalsifikasikan berdasarkan beberapa hal:

A. Berdasarkan sifat, biaya usahatani terdiri dari:

1. Biaya tetap (fixed cost), yaitu biaya relatif tetap jumlahnya dan terus dikeluarkan walaupun produksi yang diperoleh banyak atau sedikit, seperti misalnya: pajak, biaya bunga atas tanah, biaya penyusutan alat.

2. Biaya tidak tetap atau biaya berubah-ubah (variable cost), yaitu biaya yang besar kecilnya dipengaruhi oleh produksi yang diperoleh. Misalnya: biaya pembelian sarana produksi ( benih, pupuk, obatobatan dan lain-lain).

B. Berdasarkan jenis kegiatan, biaya usahatani terdiri dari:

1. Pembelian sarana produksi habis pakai Semua biaya yang dikeluarkan untuk pengadaan sarana produksi (bibit/benih, pupuk, obat-obatan, dll) yang benar-benar digunakan dalam suatu siklus produksi. Biaya pupuk misalnya adalah jumlah uang (rupiah) yang telah dibayarkan untuk jumlah pupuk yang telah terpakai.

2. Biaya bunga modal.

Uang yang diinvestasikan dalam usahatani untuk jangka waktu tertentu tidak dapat bergerak bebas, dalam arti bawah uang tersebut tidak dapat digunakan untuk keperluan lain.

3. Biaya alat produksi tahan lama
Alat-alat produksi tahan lama seperti bangunan pertanian (mis: gudang, pondok, pagar, dll), cangkul, parang, hand tracktor, bajak, dll.

4. Biaya tenaga kerja

Biaya tenaga kerja adalah besarnya upah yang dibayarkan atas tenaga kerja yang bekerja pada usahatani. Biaya tenaga kerja dikelompokan dalam dua bagian yaitu biaya tenaga kerja upahan (tenaga kerja dari luar keluarga) dan biaya tenaga kerja yang diperhitungkan (tenaga kerja dalam keluarga).

\section{Tenaga Kerja Dalam Usahatani}

Dalam Hernanto (1993) tenaga kerja merupakan salah satu unsur penentu, terutama bagi usahatani yang sangat tergantung pada musim. Kelangkaan tenaga kerja mengakibatkan mundurnya waktu penanaman sehingga berpengaruh pada pertumbuhan tanaman, produktivitas dan kualitas produk. Tenaga kerja merupakan faktor penting dalam usahatani keluarga, khususya tenaga kerja petani beserta anggota keluarganya. Rumah tangga tani yang umumnya sangat terbatas kemampuannya sangat ditentukan dari segi modal dan peranan tenaga kerja keluarga. Jika masih dapat diselesaikan oleh tenaga kerja keluarga sendiri maka tidak perlu mengupah tenaga luar, yang berarti menghemat biaya. Baik pada usahatani keluarga maupun perusahaan pertanian, peranan tenaga kerja belum sepenuhnya dapat diatasi dengan tekonologi yang menghemat tenaga (tekonologi mekanis). Hal ini dikarenakan selain mahal, juga ada hal-hal tertentu yang tidak dapat digantikan oleh selain tenaga kerja manusia.

A. Karakteristik tenaga kerja dalam usahatani.

Tenaga kerja dalam usaha tani memiliki karakteristik yang sangat berbeda dengan tenaga kerja dalam usaha bidang lain yang bukan pertanian. Karakteristik tenaga kerja dalam usahatani adalah sebagai berikut:

- Keperluan akan tenaga kerja dalam usahatani tidak kontinyu dan tidak merata.

- Penyerapan tenaga kerja dalam usahatani sangat terbatas.

- Tidak mudah distandarkan, dirasionalkan dan dispesialisasikan.

- Beraneka ragam coraknya dan kadang kala tidak dapat dipisahkan satu sama lainnya. 
Karakteristik akan memerlukan sistem manajerial tertentu yang harus dipahami sebagai peningkatan usahatani itu sendiri. Selama ini khususnya di Indonesia, sistem manajerial usahatani biasanya sangat sederhana.

\section{B. Peran petani.}

Tenaga kerja usahatani keluarga teridiri atas petani beserta keluarga dan tenaga luar yang keseluruhannya berperan dalam usahatani. Petani berperan sebagai manajer, juru tani dan manusia biasa yang hidup dalam masyarakat. Petani sebagai manajer berhadapan dengan berbagai alternatif yang harus diputuskan mana yang harus dipilih untuk diusahakan, menentukan cara produksi, cara pembelian sarana produksi, menghadapi persoalan tentang biaya, mengusahakan permodalan dan sebagainya. Untuk itu, diperlukan keterampilan, pendidikan dan pengalaman yang akan berpengaruh dalam proses pengambilan keputusan. Petani sebagai juru tani harus dapat mengatur, melaksanakan dan mengawasi kegiatan usahataninya, baik secara teknis maupun ekonomis. Disamping itu, tersedia sarana produksi dan peralatan akan menunjang keberhasilan petani sebagi juru tani.

Petani sebagai anggota
masyarakat yang hidup dalam suatu
ikatan keluarga akan selalu berusaha
memenuhi kebutuhan keluarganya. Di
samping itu, petani juga harus memenuhi
kebutuhan masyarakat atas diri dan
keluarganya. Sebaliknya, petani juga
membutuhkan bantuan masyarakat
sekelilingnya. Besar kecilnya kebutuhan
bantuan terhadap masyarakat
sekelilingnya tergantung pada teknologi
yang digunakan dan sifat masyarakat
setempat.

\section{Tenaga kerja dalam dan luar keluarga}

Peranan anggota keluarga yang lain adalah sebagai tenaga kerja disamping juga tenaga luar keluarga yang diupah. Banyak sedikitnya tenaga kerja yang dibutuhkan dalam usahatani berbeda-beda, tergantung jenis tanaman yang diusahakan. Banyak sedikitnya tenaga luar yang dipergunakan tergantung pada dana yang tersedia untuk membiayai tenaga luar tersebut. Ada beberapa hal yang membedakan antara tenaga kerja keluarga dan tenaga luar keluarga antara lain yang terbagi menurut umur, jenis kelamin, kualitas dan kegiatan kerja (prestasi kerja). Menurut Suratiyah (2015) kegiatan kerja tenaga luar keluarga sangat dipengaruhi oleh :

1. Sistem upah.

Sistem upah dibedakan menjadi tiga yaitu upah borongan, upah waktu dan upah premi. Masing-masing sistem tersebut akan mempengaruhi prestasi seorang tenaga kerja luar keluarga.

2. Lamanya waktu kerja.

Lama waktu kerja seseorang dipengaruhi oleh seseorang tersebut. Seseorang yang tidak dalam keadaan cacat atau sakit, secara normal mempunyai kemampuan untuk bekerja. Selain itu lama kerja juga dipengaruhi oleh keadaan iklim suatu tempat tertentu. Salah satu contohnya adalah wilayah tropis seperti Indonesia, untuk melakukan aktivitas lapangan seperti petani tidak dapat bertahan lama Karena cuaca yang panas.

3. Kebutuhan sehari-hari.

Kehidupan sehari-hari seorang tenaga kerja dapat dilihat pada keadaan makanan/menu dan gizi, tempat tinggal, kesehatan serta lingkungan sekitarnya, jika kondisi kurang baik dan tidak memenuhi syarat maka akan berpengaruh negatif terhadap kinerjanya.

4. Kecakapan.

Kecakapan seseorang menentukan kinerjanya. Seseorang yang lebih cakap tentu saja prestasinya lebih tinggi bila dibandingkan dengan seseorang yang kurang cakap. Kecakapan seseorang tersebut ditentukan oleh pendidikan, pengetahuan dan pengalamannya.

5. Umur tenaga kerja.

Umur seseorang menentukan prestasi kerja atau kinerja orang tersebut. Semakin tua umur tenaga kerja maka secara fisik akan terasa berat pekerjaannya, sehingga akan semakin turun pula prestasinya. Namun, dalam hal tanggung jawab semakin tua umur tenaga kerja tidak akan berpengaruh karena justru semakin berpengalaman. Sementara untuk tenaga kerja keluarga karena tidak diupah, tingginya prestasi kerja dipengaruhi oleh yang paling utama yaitu besarnya kebutuhan keluarga di samping faktorfaktor yang lain. Besarnya prestasi kerja tenaga keluarga dipengaruhi oleh perbandingan antara besarnya konsumen 
(pemakai) dalam keluarga dengan jumlah tenaga kerja yang tersedia.

Dalam Suratiyah (2015) kebutuhan tenaga kerja dapat diketahui dengan cara menghitung setiap kegiatan masing-masing komoditas yang diusahakan, kemudian dijumlah untuk seluruh usahatani. Kebutuhan tenaga kerja berdasarkan jumlah tenaga kerja keluarga yang tersedia dibandingkan dengan kebutuhannya. Berdasarkan perhitungan jika terjadi kekurangan maka untuk memenuhinya dapat berasal dari tenaga luar keluarganya. Banyaknya tenaga kerja yang diperlukan untuk megusahakan satu jenis komoditas persatuan luas dinamakan intensitas tenaga kerja. Intensitas tenaga kerja tergantung pada tingkat tekonologi yang digunakan, tujuan dan sifat usahataninya, topografi dan tanah, serta jenis komoditas yang diusahakan.

\section{Pendapatan}

\section{Pengertian Pendapatan}

Pengertian pendapatan terdapat penafsiran yang berbeda-beda bagi pihak yang berkompeten disebabkan karena latar belakang disiplin yang berbeda dengan penyusunan konsep pendapatan bagi pihak tertentu, menurut Wild (2003) secara garis besar pendapatan dapat ditinjau dari dua sisi, yaitu:

1. Pendapatan Menurut Ilmu Ekonomi

Menurut ilmu ekonomi, pendapatan merupakan nilai maksimum yang dapat dikonsumsi oleh seseorang dalam suatu priode dengan mengharapkan keadaan yang sama pada akhir priode seperti keadaan semula. Definisi pendapatan menurut ilmu ekonomi menutup kemungkinan perubahan lebih dari total harta kekayaan badan usaha pada awal priode dan menekankan pada jumlah nilai statis pada akhir periode. Dengan kata lain, pendapatan adalah jumlah kenaikan harta kekayaan karena perubahan penilaian yang bukan diakibatkan perubahan modal dan hutang.

2. Pendapatan Menurut Ilmu Akuntansi

Pandangan akuntansi memiliki keanekaragaman dalam memberikan pengertian pendapatan. Ilmu akuntansi melihat pendapatan sebagai sesuatu yang spesifik dalam pengertian yang lebih mendalam dan lebih rendah. Pada dasarnya konsep pendapatan menurut ilmu akuntansi dapat ditelusuri dari dua sudut pandang, yaitu:
- Pandangan yang menekankan pada pertumbuhan atau penigkatan jumlah aktiva yang timbul sebagai hasil dari kegiatan operasional perusahaan pendekatan yang memusatkan perhatian kepada arus masuk. Menurut SFAC (statement of financial accounting concepts) menekankan pengertian pendapatan pada arus masuk atau peningkatan-peningkatan lainnya atas aktiva suatu entitas atau penyelesaian kewajibankewajibannya atau kombinasi keduanya yang berasal dari pengiriman atau produksi barang, penyelenggara jasa, pelaksana akivitasaktivitas lainnya yang merupakan kegiatan operasi utama entitas tersebut yang berlansung terus menerus.

- Pandangan yang menekankan kepada penciptaan barang dan jasa oleh suatu usaha serta penyerahan barang dan jasa.

Menurut Kieso, Warfield dan Weygandt (2011) menjelaskan bahwa pendapatan adalah arus masuk bruto dari manfaat ekonomi yang timbul dari aktivitas normal antitas selama suatu periode, jika arus masuk tersebut mengakibatkan kenaikan ekuitas yang tidak berasal dari kontribusi penanaman modal.

Menurut Dyckman (2002) pendapatan merupakan kenaikan kotor dalam modal pemilik yang dihasilkan dari penjualan barang dagang, pelaksaan jasa pada klien, menyewakan harta, peminjaman uang dan semua kegiatan usaha profesi yang bertujuan untuk memperoleh penghasilan.

Pengertian pendapatan (revenue) sering disama artikan dengan istilah penghasilan (income), tetapi sebenarnya berbeda. Perbedaannya dijelaskan dalam definisi sebagai berikut, menurut IAI (2010) pengahsilan didefinisikan sebagai penigkatan manfaat ekonomi selama priode akuntansi dalam bentuk arus masuk atau penigkatan asset atau penurunan liabilitas yang mengakibatkan kenaikan ekuitas, yang tidak berasal dari kontribusi penanaman modal. Penghasilan (income) meliputi pendapatan (revenue) maupun keuntungan (gain).

Dari definisi tersebut dapat terlihat antara pendapatan dan penghasilan, dimana penghasilan mencakup pendapatan dan keuntungan, sedangkan pendapatan merupakan arus bruto yang berasal dari aktivitas usaha, yang berarti sebelum dikurangi biaya-biaya yang ada hubungannya dengan pendapatan tersebut. 


\section{Pendapatan Usahatani}

Di kutip dalam skripsi Kaunang (2014) pendapatan adalah bertambahnya aktiva perusahaan atau uang tunai, piutang, kekayaan lain yang berasal dari penjualan barang atau jasa yang mengakibatkan modal bertambah. Penerimaan usahatani adalah perkalian antara jumlah produksi yang diperoleh dengan harga produksi. Pendapatan usahatani adalah selisih antara penerimaan dan seluruh biaya yang dikeluarkan dalam sekali periode.

Pendapatan usahatani merupakan selisih antara penerimaan dengan semua biaya. Penerimaan usahatani adalah perkalian antara produksi yang peroleh dengan harga jual. Sedangkan menurut Sukirno (2002) pendapatan total usahatani (pendapatan bersih) adalah selisih penerimaan total dengan biaya total yang dikeluarkan dalam proses produksi, dimana semua input yang dimiliki keluarga dihitung sebagai biaya produksi.

Jenis-jenis pendapatan dalam usahatani menurut Hernanto (1993), terdapat beberpa ukuran pendapatan yaitu :

1. Pendapatan kerja petani (operator's farm labor income) adalah selisih antara semua penerima yang berasal dari penjualan produk, yang dikonsumsi keluarga dan nilai inventaris dengan semua pengeluaran baik tunai maupun tidak tunai.

2. Penghasilan kerja petani (operator's farm labor earnings) adalah pendapatan kerja petani ditambah dengan penerimaan tidak tunai seperti produk yang dikonsumsi keluarga.

3. Pendapatan kerja keluarga (family farm labor income) yaitu penghasilan kerja petani ditambah dengan nilai tenaga kerja keluarga. Ukuran ini sangat baik dgunakan apabila usahatani dikerjakan sendiri oleh petani dan keluarganya.

4. Pendapatan keluarga (family income) yaitu total pendapatan yang diperoleh petani dan keluarganya dari berbagai kegiatan.

Secara sitematis pendapatan usahatani dapat dijelaskan sebagai berikut:

$$
\mathbf{I}=\mathbf{T R}-\mathbf{T C}
$$

Dimana:

$\mathrm{I}=$ income (pendapatan)

$\mathrm{TR}=$ total revenue (total penerimaan petani)

$\mathrm{TC}=$ total cost (total biaya)

\section{Rumusan Masalah}

Usahatani campuran merupakan usaha dibidang pertanian yang diusahakan oleh warga Buton di Linkungan VII Kelurahan Airmadidi Bawah dengan jenis tanaman yang ditanam yaitu jahe-cabe, jahe-sereh, jahe-kunyit, jahe-terong, jahe-kacang tanah. Dari usahatani campuran yang diusahakan diambil 2 jenis usahatani campuran yang paling banyak diusahakan yaitu jenis usahatani campuran 1 dengan jenis tanaman jahecabe dan usahatani campuran 2 dengan jenis tanaman jahe-sereh.

Yang menjadi permasalahan dalam penelitian ini, berapa besar pendapatan rata-rata per hektar usahatani campuran berdasarkan pengelompokan jenis tanaman di Lingkungan VII Kelurahan Airmadidi Bawah?

\section{Tujuan Penelitian}

Membandingkan berapa besar pendapatan rata-rata per hektar usahatani campuran berdasarkan pengelompokan jenis tanaman di Linkungan VII Kecamatan Airmadidi Kelurahan Airmadidi Bawah.

\section{Manfaat Penelitian}

Diharapkan dapat memberikan informasi bagi petani mengenai pendapatan dalam memanfaatkan lahan secara intensif dan sebagai bahan referensi bagi penelitian selanjutnya yang berhubungan dengan masalah tersebut.

\section{METODE PENELITIAN}

\section{Waktu dan Tempat Penelitian}

Peneltian ini dilaksanakan selama 3 bulan yaitu sejak bulan September sampai bulan November 2015. Lokasi penelitian adalah Linkungan VII Kelurahan Airmadidi Bawah Kecamatan Airmadidi Kabupaten Minahasa Utara.

\section{Metode Pengambilan Data}

Data yang digunakan dalam penelitian ini adalah data primer. Data primer diperoleh secara lansung dari petani di Linkungan VII Kelurahan Airmadidi Bawah dengan menggunakan kuesioner.

\section{Metode Pengambilan Sampel}

Metode pengambilan sampel yang digunakan dalam penelitian ini adalah cluster random sampling. Dengan jumlah populasi petani adalah 142 di ambil 2 jenis usahatani yang paling 
banyak diusahakan. Jumlah sampel yang diambil adalah 15 sampel petani usahatani campuran 1 dan 15 sampel petani usahatani campuran 2.

\section{Konsep Pengukuran Variabel} adalah:

Variabel yang di ukur dalam penelitian ini

1. Usahatani campuran

- Usahatani campuran 1 :

Jenis tanaman jahe dan cabe

- Usahatani campuran 2 :

Jenis tanaman jahe dan sereh

2. Karakteristik petani :

- Umur (tahun)

- Tingkat pendidikan (SD, SMP, SMA, perguruan tinggi)

- Luas lahan yaitu luas lahan yang ditanami petani dalam satuan hektar (ha)

3. Harga (price), yaitu harga jual dari hasil panen yang berlaku di pasar Airmadidi $(\mathrm{Rp} / \mathrm{kg})$.

4. Biaya, yaitu semua pengeluaran yang dikeluarkan oleh petani mulai dari produksi sampai memasarkan produknya. Biaya-biaya ini terdiri dari : biaya tetap dan biaya variabel $(\mathrm{Rp})$.

5. Pendapatan, yaitu total penerimaan petani usahatani campuran 1 dan petani usahatani campuran 2 dikurangi total biaya produksi (Rp/satu musim tanam).

\section{Analisis Data \\ Untuk mengetahui perbandingan} pendapatan usahatani campuran di Linkungan VII Kelurahan Airmadidi Bawah dihitung pendapatan usahatani campuran dengan menggunakan analisis Pendapatan Usahatani. Pendapatan bersih petani diperoleh dengan rumus sebagai berikut :

$$
\mathbf{I}=\mathbf{T R}-\mathbf{T C}
$$

\section{Dimana,}

$$
\text { I : income (Pendapatan) }
$$

TR : Total Revenue (total penerimaan petani)

TC : Total Cost (total biaya produksi)

Selanjutnya untuk melihat perbandingan pendapatan usahatani campuran dibandingkan dengan rata-rata pendapatan usahatani campuran dengan menggunakan analisis Uji-t, dengan formula :

$$
t=\frac{\bar{x}_{1}-\bar{x}_{2}}{\sqrt{\frac{s_{1}^{2}}{n_{1}}+\frac{s_{2}^{2}}{n_{2}}}}
$$

Keterangan:

$\mathrm{X} 1$ = rata-rata pendapatan usahatani campuran 1

$\mathrm{X} 2$ = rata-rata pendapatan usahatani campuran 2

$\mathrm{S}^{2}=$ standar deviasi petani usahatani campuran 1

$\mathrm{S}^{2}=$ standar deviasi petani usahatani campuran 2

$\mathrm{n} 1=$ jumlah sampel usahatani campuran 1

$\mathrm{n} 2=$ jumlah sampel usahatani campuran 2

Dengan hipotesis :

H0 : tidak terdapat perbedaan pendapatan antara usahatani campuran 1 dengan usahatani campuran 2

H1 : terdapat perbedaan pendapatan antara usahatani campuran 1 dengan usahatani campuran 2

Dengan kriteria keputusan : Jika t-hitung > t-tabel, maka H1 diterima dan H0 ditolak Jika t-hitung < t-tabel, maka H1 ditolak dan $\mathrm{H} 0$ diterima.

\section{HASIL DAN PEMBAHASAN}

\section{Deskripsi Usahatani Campuran}

Pada umumnya masyarakat yang berada di Linkungan VII Kelurahan Airmadidi Bawah berasal dari Buton yang bermigrasi ke daerah Bitung yang bekerja sebagai nelayan lalu pindah ke daerah Airmadidi. Di Airmadidi warga Buton memulai mata pencarian mereka di bidang pertanian, karena belum memiliki lahan pribadi warga Buton memanfaatkan lahan yang ada di sekitar pemukiman untuk bercocok tanam.

Usahatani yang dilakukan warga Buton adalah usahatani campuran, dimana jenis tanaman yang ditanam lebih dari satu jenis tanaman selain itu warga Buton tidak menggunakan pupuk dalam melakukan usahatani. Metode pengambilan sampel menggunakan metode cluster random sampling dengan melakukan pemilihan data yang diambil dengan melihat 2 jenis tanaman yang paling banyak diusahakan oleh warga Buton. Jenis tanaman yang diusahakan adalah jahe-sereh, jahecabe, jahe-kunyit, jahe-terong, jahe-kacang tanah. Data yang diambil adalah sebanyak 2 jenis usaha yang paling banyak diusahakan oleh warga Buton, yaitu usahatani campuran 1 dengan jenis tanaman jahe-cabe dan usahatani campuran 2 dengan jenis tanaman jahe-sereh. 
Gambar1. Pola Tanam Usahatani Campuran

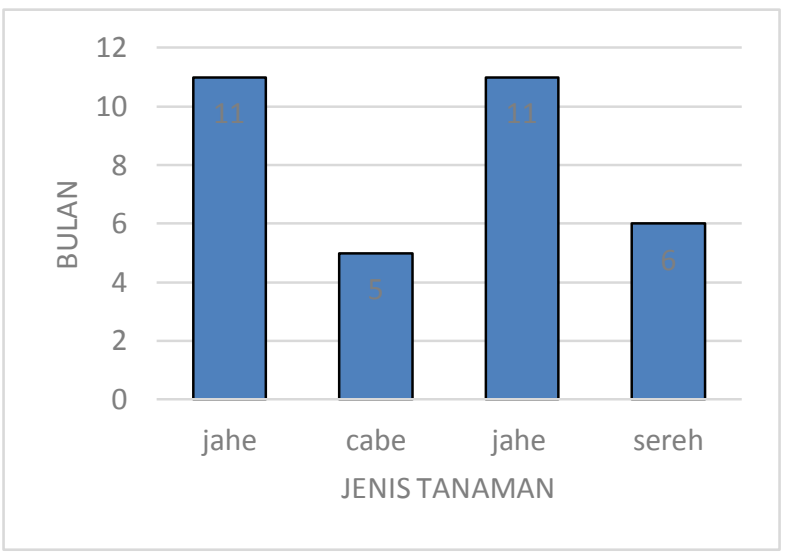

Gambar 1 menunjukan pola tanam usahatani masyarakat Buton dalam 1 musim tanam. Pola tanam yang digunakan oleh masyarakat Buton dalam melakukan usahatani campuran yaitu dengan menanam 1 jenis tanaman yang utama. Jenis tanaman utama yang ditanami warga Buton yaitu jahe. Jangka waktu panen tanaman jahe terbilang cukup lama yaitu membutuhkan waktu 9 sampai 11 bulan dalam satu musim tanam agar bisa memanen tanaman jahe sehingga warga Buton menanam jenis tanaman lain yang jangka waktu panennya lebih cepat dari tanaman jahe seperti cabe, sereh, kunyit, kemangi, terong, kacang tanah, jagung dan lain-lain. Jenis tanaman lain yang diambil dalam penelitian adalah tanaman cabe dimana jangka waktu panen tanaman cabe lebih cepat dari tanaman jahe yaitu hanya 3 sampai 5 bulan, dan tanaman sereh dimana jangka waktu penen untuk tanaman sereh berkisar 5 sampai 6 bulan.

Hasil produksi dari usahatani campuran di Linkungan VII Kelurahan Airamadidi Bawah paling banyak di jual di pasar Airmadidi. Produksi tersebut juga dipasarkan oleh pedagang pengumpul yang datang dari daerah Tondano untuk membeli jahe yang kemudian dipasarkan kembali di daerah Tondano.

\section{Karakteristik Responden.}

\section{Umur}

Umur petani sangat berpengaruh dalam proses produksi usahatani. Untuk umur responden usahatani campuran 1 dan umur responden usahatani campuran 2 di Lingkungan VII Kelurahan Airmadidi bawah dapat dilihat pada Tabel 1.

Tabel 1 menunjukan bahwa 4 responden usahatani campuran 1 dan usahatani campuran 2 berumur 33 sampai 41 tahun, dan berumur 51 sampai 59 tahun dengan jumlah persentase 26,67 persen dan responden usahatani campuran1 dan usahatani campuran 2 paling banyak berumur 42 sampai 50 tahun berjumlah 7 responden maka dengan jumlah persentase mencapai 46,67 persen.

\section{Tingkat Pendidikan}

Tingkat pendidikan responden sangat berperan dalam menentukan jenis usaha, pengalokasian input dan semua yang berkaitan dengan proses produksi. Tingkat pendidikan responden bervariasi mulai dari tidak bersekolah sampai dengan tingkat pendidikan SMA. Untuk melihat jumlah responden berdasarkan tingkat pendidikan di Lingkungan VII Kelurahan Airmadidi Bawah dapat dilihat pada Tabel 2.

Tabel 2 menunjukan bahwa sebagian besar responden berpendidikan SD dan SMP,dimana untuk responden usahatani campuran 1 paling banyak berpendidikan SD berjumlah 7 responden dengan jumlah persentase 46,67 \% dan untuk responden usahatani campuran 2 paling banyak berpendidikan SMP berjumlah 6 orang dengan jumlah persentase $40 \%$.

\section{Tabel 1. Jumlah dan Persentase Responden Berdasarkan Umur}

\begin{tabular}{cccccc}
\hline No. & Umur & \multicolumn{4}{c}{ Jumlah Responden } \\
\cline { 3 - 6 } & & $\begin{array}{c}\text { Usahatani } \\
\text { campuran 1 }\end{array}$ & Persentase (\%) & $\begin{array}{c}\text { Usahatani } \\
\text { campuran 2 }\end{array}$ & Persentase (\%) \\
\hline 1 & $33-41$ & 4 & 26,67 & 4 & 26,67 \\
2 & $42-50$ & 7 & 46,67 & 7 & 46,67 \\
3 & $51-59$ & 4 & 26,67 & 4 & 26,67 \\
\hline Total & & 15 & 100,00 & 15 & 100,00 \\
\hline
\end{tabular}

Sumber: diolah dari data primer, 2015). 
Tabel 2. Jumlah dan Persentase Responden berdasarkan Tingkat Pendidikan

\begin{tabular}{cccccc}
\hline No. & Tingkat Pendidikan & \multicolumn{5}{c}{ Jumlah Responden } \\
\cline { 3 - 6 } & & $\begin{array}{c}\text { Usahatani } \\
\text { campuran 1 }\end{array}$ & $\begin{array}{c}\text { Persentase } \\
(\%)\end{array}$ & $\begin{array}{c}\text { Usahatani } \\
\text { campuran 2 }\end{array}$ & Persentase (\%) \\
\hline 1 & Tidak Sekolah & 3 & 20 & 2 & 13,33 \\
2 & SD & 7 & 46,67 & 3 & 20 \\
3 & SMP & 3 & 20 & 6 & 40 \\
4 & SMA & 2 & 13,33 & 4 & 26,67 \\
\hline Total & & 15 & 100,00 & 15 & 100,00
\end{tabular}

Sumber:di olah dari data primer, 2015

Tabel 3. Jumlah Dan Persentase Responden Berdasarkan Jumlah Tanggungan Keluarga

\begin{tabular}{cccccc}
\hline No. & $\begin{array}{c}\text { Tanggungan } \\
\text { (orang) }\end{array}$ & \multicolumn{4}{c}{ Jumlah Responden } \\
\cline { 3 - 6 } & & $\begin{array}{c}\text { Usahatani } \\
\text { campuran } 1\end{array}$ & $\begin{array}{c}\text { Persentase } \\
(\%)\end{array}$ & $\begin{array}{c}\text { Usahatani } \\
\text { campuran } 2\end{array}$ & $\begin{array}{c}\text { Persentase } \\
(\%)\end{array}$ \\
\hline 1 & $1-2$ & 8 & 53,33 & 6 & 40 \\
2 & $>3$ & 7 & 46,67 & 9 & 60 \\
\hline Jumlah & & 15 & 100,00 & 15 & 100,00 \\
\hline
\end{tabular}

Sumber: di olah dari data primer, 2015

Tabel 4. Jumlah Dan Persentase Responden Berdasarkan Luas Lahan

\begin{tabular}{cccccc}
\hline No. & $\begin{array}{c}\text { Luas lahan } \\
\text { (ha) }\end{array}$ & \multicolumn{4}{c}{ Jumlah Responden } \\
\cline { 3 - 6 } & & $\begin{array}{c}\text { Usahatani } \\
\text { campuran 1 }\end{array}$ & Persentase (\%) & $\begin{array}{c}\text { Usahatani } \\
\text { campuran 2 }\end{array}$ & $\begin{array}{c}\text { Persentase } \\
(\%)\end{array}$ \\
\hline 1 & 0.5 & 2 & 13,33 & 1 & 6,67 \\
2 & 1 & 8 & 53,33 & 6 & 40 \\
3 & 1.2 & 2 & 13,33 & 3 & 20 \\
4 & 1.5 & 3 & 20 & 3 & 20 \\
5 & 2 & - & - & 2 & 13,33 \\
\hline Total & & 15 & 100,00 & 15 & 100,00
\end{tabular}

Sumber:di olah dari data primer, 2015. 


\section{Jumlah Tanggungan Keluarga}

Jumlah tanggungan keluarga merupakan potensi tenaga kerja dalam keluarga, ketersediaan tenaga kerja dalam keluarga sendirinya akan mengurangi pemakaian tenaga kerja dari luar keluarga. Jumlah tanggungan keluarga responden dapat dilihat pada Tabel 3. Tabel 3 menunjukan bahwa tanggungan keluarga responden usahatani campuran 1 dan responden usahatani campuran 2. Dimana responden usahatani campuran 1 ada 8 responden memiliki tanggungan keluarga antara 1 dan 2 orang dengan jumlah persentase sebesar $53.33 \%$ dan 7 responden memiliki tanggungan keluarga lebih dari 3 orang dengan jumlah persentase sebesar $46.67 \%$ dan responden usahatani campuran 2 ada 6 responden memiliki tanggungan keluarga antara 1 dan 2 orang dengan jumlah persentase sebesar $40 \%$ dan 9 responden memiliki tanggungan keluarga lebih dari 3 orang dengan jumlah perentase sebesar $60 \%$.

\section{Luas Lahan Garapan Responden}

Perbedaan luas lahan garapan akan berpengaruh pada pendapatan petani. Keadaan lahan serta luas lahan akan mempengaruhi produksi, biaya dan penggunaan tenaga kerja dalam melakukan proses produksi. Luas lahan yang dimiliki responden selama proses produksi dapat dilihat pada Tabel 4.Tabel 4 menunjukan sebanyak 8 responden untuk usahatani campuran 1 memiliki luas lahan sebesar 1 ha dan 6 responden untuk usahatani campuran 2 memiliki luas lahan sebesar 1 ha. 2 responden usahatani campuran 1 dan 1 responden usahatani campuran 2 memiliki lahan seluas 0.5 ha, 2 responden usahatani campuran 1 dan 3 responden usahatani campuran 2 memiliki lahan seluas 1.2 ha, untuk usahatani campuran 1 dan usahatani campuran 2 sebanyak 3 responden memiliki luas lahan yang sama yaitu sebesar 1.5 ha, dan 2 responden usahatani campuran 2 memilikki lahan seluas 2 ha.

\section{Biaya, Penerimaan dan Pendapatan Usahatani Campuran.}

\section{Biaya-biaya produksi}

Biaya tetap usahatani campuran di Lingkungan VII Kelurahan Airmadidi Bawah adalah biaya penyusutan alat-alat pertanian.
Penyusutan alat merupakan biaya yang perlu dimasukan ke dalam perhitungan biaya tetap. Alat-alat pertanian yang biasa digunakan oleh petani di Lingkungan VII Airmadidi Bawah seperti cangkul, parang, sekop dan pisau kecil atau dalam sebutan warga Buton adalah " $k u d a-$ $k u d a "$, setelah penggunaan alat-alat pertanian beberapa tahun alat-alat pertanian akan mengalami biaya penyusutan. Biaya penyusutan alat-alat pertanian dapat di lihat pada Tabel 5. Data pada Tabel 5 menunjukan bahwa untuk biaya penyusutan alat-alat pertanian untuk usahatani campuran di Lingkungan VII Kelurahan Airmadidi Bawah. Biaya penyusutan alat-alat pertanian usahatani campuran 1 adalah Rp 1.044.161 dengan jumlah alat sebanyak 121 dan rata-rata biaya penyusutan alat-alat pertanian per hektar sebesar Rp. 69.611, dan biaya penyusutan alat-alat pertanian usahatani campuran 2 adalah Rp 996.452 dengan jumlah alat sebanyak 118 dan rata-rata biaya penyusutan alat-alat pertanian per hektar sebesar Rp. 66.430. Biaya variabel usahatani campuran di Lingkungan VII Kelurahan Airmadidi Bawah meliputi biaya pengadaan benih, biaya tenaga kerja dan biaya pengangkutan hasil produksi.

Biaya variabel usahatani campuran di Lingkungan VII Kelurahan Airmadidi Bawah dapat dilihat pada Tabel 6. Tabel 6 menunjukan bahwa biaya variabel untuk Usahatani campuran 1 adalah $\mathrm{Rp} 57.125 .000$ dengan ratarata biaya per hektar sebesar Rp 3.808.333, dan biaya variabel usahatani campuran 2 adalah $R p$ 59.010.000 dengan rata-rata biaya per hektar sebesar Rp. 3.934.000. Selanjutnya untuk melihat total biaya produksi usahatani campuran di Lingkungan VII Kelurahan Airmadidi Bawah dapat dilihat pada Tabel 7.

Tabel 7 menunjukan total biaya produksi usahatani campuran yang ada di Lingkungan VII Kelurahan Airmadidi Bawah. Yaitu total biaya tetap di tambah dengan total biaya variabel. Total biaya produksi usahatani campuran 1 adalah $\mathrm{Rp} 58.169 .161$ dengan ratarata biaya produksi per hektar sebesar $\mathrm{Rp}$ 3.877.944 dan total biaya produksi usahatani campuran 2 adalah Rp 60.006.452 dengan ratarata biaya produksi per hektar sebesar $\mathrm{Rp}$ 4.000.431. 
Tabel 5. Biaya Penyusutan Alat-alat Pertanian Usahatani campuran 1 Dan Usahatani Campuran 2

\begin{tabular}{|c|c|c|c|c|c|}
\hline \multirow[t]{2}{*}{ No. } & \multirow[t]{2}{*}{ Uraian } & \multicolumn{2}{|c|}{ Usahatani campuran 1} & \multicolumn{2}{|c|}{ Usahatani campuran 2} \\
\hline & & Jumlah alat & $\begin{array}{l}\text { Jumlah biaya } \\
\text { (Rp) }\end{array}$ & Jumlah alat & $\begin{array}{c}\text { Jumlah biaya } \\
(\mathrm{Rp})\end{array}$ \\
\hline 1 & $\begin{array}{c}\text { Biaya } \\
\text { penyusutan }\end{array}$ & 121 & 1.044 .161 & 118 & 996.452 \\
\hline $\begin{array}{c}\text { Rata-rata } \\
\text { biaya }\end{array}$ & & & 69.611 & & 66.430 \\
\hline
\end{tabular}

Tabel 6. Biaya Variabel Usahatani Campuran 1 Dan Usahatani Campuran 2

\begin{tabular}{ccc}
\hline Uraian & Usahatani campuran 1 & Usahatani campuran 2 \\
\hline Pengadaan benih & 8.050 .000 & 10.100 .000 \\
Biaya tenaga kerja & 43.275 .000 & 43.010 .000 \\
Biaya pengangkutan & 5.800 .000 & 5.900 .000 \\
\hline Total & 57.125 .000 & 59.010 .000 \\
\hline Rata-rata biaya/ha & 3.808 .333 & 3.934 .000
\end{tabular}

Sumber: di olah dari data primer,2015

Tabel 7. Total Biaya Produksi Usahatani Campuran 1 dan Usahatani Campuran 2

\begin{tabular}{ccc}
\hline Jenis biaya & Usahatani campuran 1 & Usahatani campuran 2 \\
\hline Biaya tetap & 1.044 .161 & 996.452 \\
Biaya variabel & 57.125 .000 & 59.010 .000 \\
\hline Total & 58.169 .161 & 60.006 .452 \\
\hline Rata-rata biaya/ha & 3.877 .944 & 4.000 .431
\end{tabular}

Sumer: di olah dari data primer, 2015

Tabel 8. Jumlah Produksi Dan Penerimaan Usahatani Campuran 1 Dan Usahatani Campuran 2

\begin{tabular}{ccccccc}
\hline Uraian & \multicolumn{3}{c}{ Usahatani campuran 1 } & \multicolumn{3}{c}{ Usahatani campuran 2 } \\
\cline { 2 - 6 } & $\begin{array}{c}\text { Jahe } \\
(\mathrm{kg})\end{array}$ & $\begin{array}{c}\text { Cabe } \\
(\mathrm{kg})\end{array}$ & $\begin{array}{c}\text { Penerimaan } \\
(\mathrm{Rp})\end{array}$ & Jahe $(\mathrm{kg})$ & $\begin{array}{c}\text { Sereh } \\
\text { (tangkai) }\end{array}$ & $\begin{array}{c}\text { Penerimaan } \\
(\mathrm{Rp})\end{array}$ \\
\hline $\begin{array}{c}\text { Jumlah } \\
\text { produksi }\end{array}$ & 30.300 & 4.790 & & 26.600 & 97.090 & \\
$\begin{array}{c}\text { Rata-rata } \\
\text { harga jual }\end{array}$ & 18.800 & 6.000 & 596.990 .000 & 18.900 & 166 & 516.466 .940 \\
\hline Total & & 596.990 .000 & & & 316.466 .940 \\
\hline $\begin{array}{c}\text { Rata-rata } \\
\text { penerimaa } \\
\text { n/ha }\end{array}$ & & 39.799 .333 & & \\
\hline
\end{tabular}

Sumber: di olah dari data primer, 2015.

Tabel 9. Pendapatan Usahatani Campuran 1 Dan Usahatani Campuran 2

\begin{tabular}{ccc}
\hline Uraian & Usahatani campuran 1 & Usahatani campuran 2 \\
\hline Biaya produksi & 58.169 .161 & 60.006 .452 \\
Penerimaan & 596.990 .000 & 516.466 .940 \\
\hline Pendapatan & 538.820 .839 & 456.460 .088 \\
\hline Rata-rata pendapatan/ha & 35.921 .389 & 30.430 .699
\end{tabular}

Sumber: di olah dari data primer, 2015. 


\section{Penerimaan Usahatani Campuran}

Penerimaan usahatani adalah perkalian antara jumlah produksi yang diperoleh dengan harga jual produk. Untuk melihat jumlah produksi dan penerimaan petani di Lingkungan VII Kelurahan Airmadidi Bawah yang dihasilkan dalam 1 musim tanam dapat dilihat pada Tabel 8 .

Tabel 8 menunjukan bahwa jumlah produksi Usahatani campuran 1 terdiri dari $30.300 \mathrm{~kg}$ jahe dan $4.790 \mathrm{~kg}$ cabe dan untuk Usahatani campuran 2 terdiri dari $26.600 \mathrm{~kg}$ jahe dan 97.090 tangkai sereh. Dengan total penerimaan usahatani campuran 1 adalah Rp. 596.990.000 dengan rata-rata penerimaan per hektar sebesar Rp. 39.799.333, dan total penerimaan usahatani campuran 2 adalah Rp. 516.466.940 dengan rata-rata penerimaan per haktar sebesar Rp. 34.431.129.

\section{Pendapatan Usahatani Campuran}

Pendapatan merupakan selisih antara penerimaan dengan semua biaya atau total biaya produksi. Menurut Sukirno (2002) pendapatan total usahatani (pendapatan bersih) adalah selisih penerimaan total dengan biaya total yang dikeluarkan dalam proses produksi, dimana semua input yang dimiliki keluarga dihitung sebagai biaya produksi. Pendapatan usahatani campuran di Linkungan VII Kelurahan Airmadidi Bawah dapat dilihat pada Tabel 9.

Tabel 9 menunjukan total pendapatan usahatani campuran untuk Usahatani campuran 1 sebesar Rp 538.020.839 dengan rata-rata pendapatan per hektar adalah Rp 35.921.389, untuk Usahatani campuran 2 total pendapatan sebesar Rp 456.460.088 dengan rata-rata pendapatan per hektar adalah Rp 30.430.699.

Setelah pengambilan data untuk masing-masing responden dilakukan, selanjutanya untuk membandingkan pendapatan dari masing-masing responden diambil rata-rata pendapatan per hektar dari setiap responden.

Selanjutnya untuk melihat perbandingan pendapatan usahatani campuran di Lingkungan VII Kelurahan Airmadidi Bawah, maka dilakukan uji beda rata-rata atau uji-t dengan menggunakan bantuan software SPSS. Data yang akan di uji adalah rata-rata pendapatan per hektar dari masing-masing responden usahatani campuran 1 dengan rata-rata pendapatan per hektar dari masing-masing responden usahatani campuran 2 . Untuk hasil pengujian dengan menggunakan software SPSS dapat dilihat pada lampiran 7.
Dari hasil pengujian statistik dengan menggunakan uji-t menunjukan bahwa rata-rata pendapatan usahatani campuran 1 berbeda nyata dengan rata-rata pendapatan usahatani campuran 2.

Berikut hasil dari uji hipotesis usahatani campuran 1 dan usahatani campuran 2 dimana thitung $(4,910)>\mathrm{t}$-tabel $(1,761)$. Dari hasil pengujian maka, Ho di tolak dan H1 di terima, itu berarti bahwa terdapat perbedaan pendapatan antara usahatani campuran 1 dengan usahatani campuran 2. Penyebab terdapatnya perbedaan pendapatan rata-rata per hektar usahatani campuran 1 dan usahatani campuran 2 adalah adanya harga jual cabe yang tinggi pada usahatani campuran 1 .

\section{KESIMPULAN DAN SARAN}

\section{Kesimpulan}

Dari penelitian yang dilakukan di Lingkungan VII Kelurahan Airmadidi Bawah, dapat disimpulkan bahwa antara pendapatan rata-rata per hektar usahatani campuran 1 (jahecabe) berbeda nyata dengan rata-rata pendapatan per hektar usahatani campuran 2 (jahe-sereh).

\section{Saran}

Hasil penelitian yang telah dilakukan diketahui usahatani campuran 1 memiliki pendapatan lebih besar dari usahatani campuran 2, ada baiknya warga Buton lebih mengembangkan usahatani campuran 1 untuk mendapatakan pendapatan yang lebih tinggi dengan mempertimbangkan iklim dan harga jual saat panen dari jenis tanaman yang akan diusahakan.

\section{DAFTAR PUSTAKA}

Adrianto, T. 2014. Pengantar Ilmu Pertanian: Agraris, Agrobisnis, Agroindustry dan Agroteknologi. Edisi 1. Yogyakarta

Agustyari, N.K. 2013. Perbandingan Pendapatan Usahatani Jagung Manis dan Padi di Subak Delod Sema Padanggalak Desa Kesiman Petilan Kecamatan Denpasar Timur. Skripsi. Universitas Udayana. Bali 
Dyckman, Dukes R,Charles J. 2000. Akuntansi Intermediate. Edisi ke 3. Jillid 1. Diterjemahkan oleh Munir Ali. Jakarta. Erlangga

Eliana. A. 2015. Perbandingan Pendapatan Petani Kacang di Desa Tombasian Atas Kecamatan Kawangkoan Barat Kabupaten Minahasa. Skripsi. Universitas Sam Ratulangi. Manado

Hernanto, F. 1993. Ilmu Usaha Tani. PT. Penebar Swadaya. Jakarta

Hanafie, R. 2010. Pengantar Ekonomi Pertanian: edisi 1. C.V ANDI OFFSET. Yogyakarta

Harahap, S. 2008. Teori Akuntansi. Jakarta. PT. Raja Grafindo Persada

Ikatan Akuntansi Indonesia. 2012. Pernyataan Standar Akuntansi Keuangan PSAK. No.23

Kieso, Weygant J, Warfield T. 2011. Intermediate Accounting. IFRS edition. Volume 2. Jakarta

Kaunang, A. 2014. Perbandingan Pendapatan Petani Pala Pada Berbagai Saluran Pemasaran di Kecamatan Kauditan Kabupaten Minahasa Utara. Skripsi. Universitas Sam Ratulangi. Manado

Khaerizal, H. 2008. Analisis Pendapatan dan Faktor-Faktor Produksi Usahatani Komoditi Jagung Hibrida dan Bersari Bebas (lokal). Skripsi. Institut Pertanian Bogor

Pontoh, S. 2014. Perbandingan Pendapatan Petani Padi Sawah Peserta dan Bukan Peserta Pasar Lelang Komoditi Agro ( PLKA) di
Kelurahan Kiniar Kecamatan Tondano Timur. Skripsi. Universitas Sam Ratulangi. Manado

Rochaeni, S. 2014. Pembangunan Pertanian Indonesia edisi 2. GRAHA ILMU. Yogyakarta

Sugiyono. 2014. Metode Penelitian Bisnis. Pendekatan Kuantitatif, Kualitatif dan R\&D. Alfabeta. Bandung.

Sukirno, S. 2002. Pengantar Teori Ekonomi Mikro. PT. Raja Grafindo Persada. Jakarta

Sukino. 2014. Membangun Pertanian Dengan Pemberdayaan Masyarakat Tani: Terobosan Menanggulangi Kemiskinan. Yokyakarta

Sukoco, S. 1999. Pertanian Masa Depan: Pengantar Untuk Pertanian Berkelanjutan Dengan Input Luar Rendah. KANISIUS. Yogyakarta

Suratiyah, K. 2015. Ilmu Usaha Tani: Edisi revisi. Penebar Swadaya. Jakarta

Suwardjono. 2010. Teori Akuntansi, Perekayasa Pelaporan Keuangan. Edisi ke 3. Yokyakarta. BPFE

Tigauw, N. 1998. Analisis Pendapatan Usahatani Padi Gogo Sebagai Tanaman Sela di Lahan Pertanian Kelapa. Skripsi. Universitas Sam Ratulangi. Manado

Wijayanti. V. 2010. Usahatani Kakao dan Tingkat Ekonomi Petani di Desa Banjarasri Kecamatan Kalibawang Kabupaten Kulon Progo. Skripsi. Universitas Negeri Yogyakarta 